\title{
Prognosis and Staging of AL Amyloidosis
}

\author{
Tobias Dittrich $^{\mathrm{a}, \mathrm{b}}$ Christoph Kimmich ${ }^{\mathrm{a}, \mathrm{b}}$ Ute Hegenbart ${ }^{\mathrm{a}, \mathrm{b}}$ \\ Stefan O. Schönland ${ }^{a, b}$ \\ ${ }^{a}$ Department of Internal Medicine V, Division of Hematology/Oncology, Heidelberg University Hospital, Heidelberg,

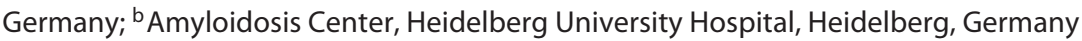

\section{Keywords}

Survival · Biomarkers · Prognostic factors $\cdot$ Staging systems

\begin{abstract}
The treatment options for systemic light chain amyloidosis (AL) are currently widening in an unprecedented way, brought about by an expanding arsenal of anti-myeloma therapy as well as by novel approaches to target toxic light chains and, most recently, deposited amyloid directly. In this context, accurate estimates of prognosis in $\mathrm{AL}$, which allow for reliable patient advice and for example comparison of different therapies, are particularly important to clinicians. Some biomarkers and especially the genetic background of the underlying clonal disease as evaluated by interphase fluorescence in situ hybridization even have predictive value, enabling an appropriate treatment selection. Derived from the most frequently involved organs in AL, heart and kidney, this review focuses on overall survival and renal survival. A comprehensive overview and summary of reported prognostic factors and biomarkers in AL is given and the most important and validated factors are highlighted. Finally, established staging systems in AL as well as validated and perspective response criteria are presented.
\end{abstract}

(c) 2020 S. Karger AG, Basel
(C) 2020 S. Karger AG, Basel

www.karger.com/aha

Karger"

\section{Introduction}

Light chain amyloidosis (AL) is a heterogeneous and life-threatening disease caused by misfolded free light chains (FLC) that typically originate from small plasma cell clones and in rare cases B-cell clones. Although less than $10 \%$ of AL patients qualify for CRAB criteria [1], the majority of these patients have a significant impairment of vital organs, such as the heart, kidney, and liver [2]. This implies that myeloma risk factors are usually not applicable in AL patients. Due to the complexity of AL, several factors determine the prognosis and have to be considered. Although this review does not claim to be exhaustive, biomarkers and factors that were of prognostic value for AL patients in large clinical studies are presented in Tables 1 and 2. The most important factors and biomarkers are discussed in greater detail within the text.

We discriminate plasma cellular factors on the one hand, which correspond to the pathogenic light chains and underlying clonal bone marrow disorder and, on the other hand, organ biomarkers, which reflect the end-organ damage caused by the toxic FLC and the deposited amyloid fibrils. The (early) prognosis of AL patients is almost entirely determined by the amyloidogenic end-organ damage, with severe heart involvement conferring 
Table 1. Prognostic significance of plasma cellular factors/biomarkers at time of baseline assessment

\begin{tabular}{|c|c|c|c|c|}
\hline \multirow[t]{2}{*}{ Plasmacytosis } & BM cytology or histology & $\begin{array}{l}>10 \% \\
\geq 20 \%\end{array}$ & $\begin{array}{l}\text { Adverse OS and PFS in MVA } \\
\text { Adverse OS in MVA }\end{array}$ & $\begin{array}{l}1,3,4 \\
5\end{array}$ \\
\hline & PBPC & $>5 \times 10^{5} / \mathrm{L}$ & Adverse OS (limited MVA) & 8 \\
\hline M protein & Urine & Cont. or $>1 \mathrm{~g} / 24 \mathrm{~h}$ & Adverse OS in MVA & 9,10 \\
\hline Immunoparesis ${ }^{1}$ & $\begin{array}{l}\text { All uninvolved Ig } \\
\text { in serum }\end{array}$ & $\begin{array}{l}\text { Below lower limit } \\
\text { of normal }\end{array}$ & $\begin{array}{l}\text { Adverse OS in MVA and in patients with cardiac involvement, } \\
\text { poor response to first-line treatment }\end{array}$ & 16,17 \\
\hline $\begin{array}{l}\text { Any chromosomal } \\
\text { aberration }\end{array}$ & FISH/BM & Presence & $\begin{array}{l}\text { Increased plasmacytosis, cardiac involvement, adverse OS } \\
\text { in MVA }\end{array}$ & 18,19 \\
\hline Gain of 1q21 & FISH/BM & Presence & Adverse OS and EFS in MVA or UVA (M-Dex, daratumumab) & 23,24 \\
\hline Deletion of $17 \mathrm{p}$ & $\mathrm{FISH} / \mathrm{BM}$ & $>50 \%$ cells & Trend towards shorter OS & 25 \\
\hline Trisomies & FISH/BM & Presence & Adverse OS in MVA (generally or if $>10 \%$ BM plasmacytosis) & 19,21 \\
\hline $\begin{array}{l}\text { BM, bone mar } \\
\text { progression-free } \\
\text { minus uninvolved } \\
\text { melphalan + autol } \\
{ }^{1} \text { Defined as th }\end{array}$ & $\begin{array}{l}\text { MFC, multiparametric } \\
\text { val; MVA, multivariate } \\
\text {; FISH/BM, fluorescenc } \\
\text { us stem cell transplantat }\end{array}$ & $\begin{array}{l}\text { cytometry; PBPC, cir } \\
\text { ysis; UVA, univariate } \\
\text { situ hybridization of } \mathrm{p}\end{array}$ & $\begin{array}{l}\text { ing peripheral blood plasma cells; Cont., continuous; OS, overall s } \\
\text { ysis; FLC, free light chains; iFLC, involved FLC; dFLC, difference } \\
\text { a cells from bone marrow aspiration; EFS, event-free survival; HDI }\end{array}$ & $\begin{array}{l}\text { vival; PFS, } \\
\text { f involved } \\
\text { high-dose }\end{array}$ \\
\hline
\end{tabular}

the worst prognosis. However, some plasma cellular factors are associated with a specific organ involvement pattern. The most important association, although not causatively clarified, is that the severity of heart involvement seems to depend on the serum FLC levels at initial diagnosis, while renal involvement is frequently found with lower circulating FLC $[2,14,39]$. When it comes to chemotherapy, plasma cellular factors gain prognostic value independent of or in addition to organ biomarkers. In specific cases, the mutational background of the clonal plasma cell is even predictive for the response to different treatment regimens $[20,21,24]$.

\section{Prognostic Value of Plasma Cellular Factors in AL Amyloidosis}

\section{Free Light Chains}

The diagnosis and monitoring of AL patients were revolutionized by the introduction of a polyclonal antibodybased nephelometric assay for quantification of serum FLC (Freelite, Binding Site, UK) [40, 41]. One decade lat- er, another commercial assay based on monoclonal antibodies became available. Both assays are currently used in diagnostic laboratories. It is important to note that the assays perform very differently in clinical practice and cannot be used interchangeably [42]. All work presented in this review and the validated thresholds used by the $\mathrm{AL}$ community refer to the initially introduced Freelite assay.

The FLC detection provided the possibility to quantify the amyloid-precursor protein itself, which obviously makes such an assay advantageous in AL. Moreover, an FLC test is also applicable in patients who lack an intact immunoglobulin, which is the majority of cases in AL [2, 27]. Last but not least, the FLC tests are quite sensitive and as such more suitable for the usually small plasma cell clones in AL compared to other plasma cellular factors. Several studies proved and validated the prognostic significance of serum FLC for overall survival (OS) in AL [2, 11-14], and the FLC test soon became regarded as essential for the diagnosis and monitoring of treatment response in the international consensus guidelines for $\mathrm{AL}$ amyloidosis care [43]. Various thresholds for the difference between involved and uninvolved FLC (dFLC) were 
Table 2. Prognostic significance of individual organ factors/biomarkers at time of baseline

\begin{tabular}{|c|c|c|c|c|}
\hline Factor/biomarker & Medium & Threshold & Prognostic significance & Ref. No. \\
\hline NT-proBNP & Serum & $\begin{array}{l}\geq 152 />332 />1,800 />2,736 \mathrm{pg} / \mathrm{mL} \\
>8,500 \mathrm{pg} / \mathrm{mL}\end{array}$ & $\begin{array}{l}\text { Adverse OS in MVA } \\
\text { Adverse OS in MVA (within high-risk } \\
\text { subgroup of patients) }\end{array}$ & $\begin{array}{l}10,12,15,26,27 \\
28\end{array}$ \\
\hline $\mathrm{BNP}$ & Serum & $\begin{array}{l}>81 \mathrm{pg} / \mathrm{mL} \\
>700 \mathrm{pg} / \mathrm{mL}\end{array}$ & $\begin{array}{l}\text { Equivalent to NT-proBNP }>332 \mathrm{pg} / \mathrm{mL} \\
\text { Equivalent to NT-proBNP }>8,500 \mathrm{pg} / \mathrm{mL}\end{array}$ & $\begin{array}{l}29 \\
29\end{array}$ \\
\hline cTNT & Plasma or serum & Cont. or $>0.03 / \geq 0.035 \mu \mathrm{g} / \mathrm{L}$ & Adverse OS in MVA & $9,10,15$ \\
\hline cTNI & Plasma or serum & Cont. or $>70 />100 \mathrm{ng} / \mathrm{L}$ & Adverse OS in MVA & $9,10,12$ \\
\hline hs-cTNT & Plasma or serum & Cont. or $\geq 14 / \geq 50 / \geq 54 />77 \mathrm{ng} / \mathrm{L}$ & Adverse OS in MVA & $12,30,31$ \\
\hline Ejection fraction & $\begin{array}{l}\text { Echo (LVEF) } \\
\text { MRI (MCF) }\end{array}$ & $\begin{array}{l}\text { EF Cont. or }<45 \% /<50 \% \\
\mathrm{MCF} \leq 56.6 \%\end{array}$ & Adverse OS in MVA & $9,10,31,32$ \\
\hline $\begin{array}{l}\text { LV longitudinal } \\
\text { function }\end{array}$ & $\begin{array}{l}\text { Echo (GLS) } \\
\text { MRI (LAS) }\end{array}$ & $\begin{array}{l}\text { GLS }<-11.8 \% \\
\text { LAS }<-7 \%\end{array}$ & Adverse OS in MVA & $32-34$ \\
\hline Septum thickness & Echo & Cont. or $>15 \mathrm{~mm}$ & Adverse OS in MVA & 9,10 \\
\hline NYHA class & Clinical examination & $>2$ & Adverse OS in MVA & 12 \\
\hline $\begin{array}{l}\text { Systolic blood } \\
\text { pressure }\end{array}$ & clinical examination & $<100 \mathrm{~mm} \mathrm{Hg}$ & $\begin{array}{l}\text { Adverse OS in MVA (within high-risk } \\
\text { subgroup of patients) }\end{array}$ & 28 \\
\hline Atrial arrhythmia & ECG/clinical examination & presence & Adverse OS in MVA & 35,36 \\
\hline EGFR & From serum creatinine & $<50 \mathrm{~mL} / \mathrm{min}$ & Favorable OS in MVA, adverse RS in MVA & 35,37 \\
\hline Uric acid & Serum & $>8 \mathrm{mg} / \mathrm{dL}$ & Adverse OS in MVA & 38 \\
\hline Albumin & Serum & Cont. or $\leq 30 \mathrm{~g} / \mathrm{L}$ & Adverse OS in MVA, adverse RS in UVA & 10,37 \\
\hline Proteinuria & Urine & $>5 \mathrm{~g} / 24 \mathrm{~h}$ & Adverse RS in MVA & 37 \\
\hline $\begin{array}{l}\text { Albumin-to- } \\
\text { creatinine ratio }\end{array}$ & Urine & $>220 \mathrm{mg} / \mathrm{mmoL}$ & $\begin{array}{l}\text { Adverse EFS in MVA (daratumumab-based } \\
\text { regimens) }\end{array}$ & 23 \\
\hline
\end{tabular}

OS, overall survival; Cont., continuous; MVA, multivariate analysis; LVEF, left ventricular ejection fraction; GLS, global longitudinal strain; ECG, electrocardiogram; EGFR, estimated glomerular filtration rate; RS, renal survival; MCF, myocardial contraction fraction; LAS, long axis strain.

shown to be prognostic (Tables 1,2), indicating that dFLC could also be regarded as a continuous risk factor. The threshold of $180 \mathrm{mg} / \mathrm{L}$ is well validated and used as part of an AL staging system $[15,35]$. Serum FLC levels are closely correlated with amyloidogenic end-organ damage. A high dFLC is associated with more frequent and more severe organ involvement and dysfunction, especially heart, translating into an unfavorable prognosis independent of other factors $[2,13,41]$. On the other hand, AL patients with a low $\mathrm{dFLC}$ represent a distinct clinical subgroup with a favorable prognosis and preferentially kidney involvement $[2,14]$.

The nephelometric FLC test does not distinguish between the clonal light chains and unspecific polyclonal background. Unspecific accumulation of serum FLC frequently occurs with impaired renal function and might limit the significance of FLC blood levels [44]. This po- tentially impedes the identification of the amyloidogenic light chain and the prognostic assessment in many patients with AL amyloidosis [45]. The FLC K/L ratio is less dependent on kidney function and therefore used for diagnosis of the disease rather than absolute FLC levels alone [44]. Moreover, the dFLC is routinely used for monitoring of the disease [46]. Nevertheless, the detection of very small clones and detection of early relapse in $\mathrm{AL}$ is challenging with the current standard techniques. Mass spectrometry-based analyses have shown superiority in detecting clonal disease and should further improve prognostication and response evaluation in AL [47].

\section{Plasma Cellular Burden}

The bone marrow diagnostic is important for making the initial diagnosis of systemic AL and characterizing the underlying clonal disease. Although a high plasma cell 
burden in AL usually translates into higher levels of amyloidogenic FLC $[3,41]$, this association depends on the one hand on the secretory activity of individual plasma cell clones and on the other hand on the elimination from the serum; therefore, this assumption does not always hold true. However, a higher plasma cellular burden in bone marrow cytology or histology, or even the detection in peripheral blood, reflects a higher disease activity and is prognostically adverse for OS in AL [1,3-5], while smaller clones commonly have a deeper and longer response to treatment $[2,14]$. Multiparametric flow cytometry emerged as a reliable tool for the detection of small plasma cell clones in bone marrow aspirates and the prognostic value of this analysis in AL could be demonstrated by several groups $[6,7,48]$. It was also shown that immunoparesis, an adverse prognostic marker in plasma cell proliferative disorders, predicts the response to first-line therapy and confers an independent prognostic marker in $\operatorname{AL}[16,17]$.

Before the establishment of the FLC test, M protein was used to assess the clonal size. Urine $M$ protein and not serum $M$ protein was reported to be prognostic in multivariate analyses $[9,10]$. This again indicates that light chains, which often concentrate in the urine of $\mathrm{AL}$ patients with renal involvement or excessive serum light chain burden, have a higher prognostic value compared to the clonal heavy chains. The absence of the heavy chain is an independently negative prognostic factor for OS, suggesting that unbound light chains may be inherently more prone to undergo misfolding into an amyloid configuration [13].

\section{Genetics of Plasma Cell Clones}

The prognostic value of fluorescence in situ hybridization (FISH) abnormalities has been well established in MM for decades [49]. Soon it became evident that FISH abnormalities were also independent prognostic factors in AL $[24,50]$. Most of the AL patients (70-90\%, depending on the cohort and sensitivity of the analysis) have detectable cytogenetic abnormalities with iFISH $[19,21,50$, 51]. However, the genetic landscape of plasma cell clones from AL patients differs compared to myeloma patients. Hyperdiploidy and features regarded as high risk in MM are less common in AL. In contrast, there is a much higher prevalence of translocations involving the immunoglobulin heavy chain locus, which is suspected to be an early event in the clonal evolution of gammopathies [52]. Translocation $t(11 ; 14)$ is a hallmark of AL amyloidosis and is associated with the Bence Jones phenotype as well as less complex clonal landscape $[20,53]$.

Prognosis and Staging of AL Amyloidosis
It is understandable that the genetic background of the plasma cell clone provides additional prognostic information to the mere secretory capacity. One reason is that the efficacy of chemotherapeutical regimens seems to be closely linked to the mutational landscape of the plasma cell $[20,24,54]$. Therefore, the FISH diagnostic is potentially more important for long-term outcome of AL patients and should mostly be judged in combination with the therapeutic regimen.

Myeloma high-risk cytogenetics $(t(4 ; 14), t(14 ; 16)$, del17) are rare in AL and not an unfavorable prognostic factor in AL patients treated with bortezomib [20], while more complex karyotype clones and higher rates of del17 have a slightly worse prognosis $[19,21,25]$. Gain of 1q21 is an independent adverse prognostic factor in AL amyloidosis patients treated with melphalan and dexamethasone standard chemotherapy as well as with daratumumab $[23,24]$. In contrast, $t(11 ; 14)$ is an unfavorable independent prognostic factor in AL patients treated with bortezomib [20, 21]. However, ASCT and daratumumab at least overcome this negative impact $[21-23,55]$.

These findings strongly suggest that a risk-adapted treatment in AL amyloidosis has to recognize FISH diagnostic [56]. For example, patients with $t(11 ; 14)$ preferentially receive high-dose therapy with stem cell transplant or melphalan-based chemotherapy [55]. Recently, it was found that myeloma cells with $t(11 ; 14)$ show a particularly high expression of the anti-apoptotic protein Bcl-2 [54], indicating susceptibility to Bcl-2 inhibition by venetoclax and supporting the predictive value of FISH diagnostic in AL patients. A series of case reports presented excellent results with venetoclax for treatment of myeloma and AL amyloidosis with $t(11: 14)$ [57-59].

\section{IgM-Related AL Amyloidosis}

In $5-10 \%$ of cases, AL is caused by an IgM paraprotein, often secreted by a B-cell clone $[60,61]$ and rarely by a plasma cell clone. IgM AL is regarded as a distinct clinical entity with several clinical features and organ involvement patterns, which distinguish it from nonIgM AL amyloidosis. Therefore, the prognostic values of the aforementioned factors can only be transferred with caution to this clinical entity of AL amyloidosis. A revised staging system combining liver involvement and the presence of neuropathy with the established factors elevated NT-proBNP and troponin was proposed for this disease [61], but requires further validation. It is critical for the prognosis of IgM-AL that diagnosis and treatment is directed at the underlying clonal disease $[60,61]$. 


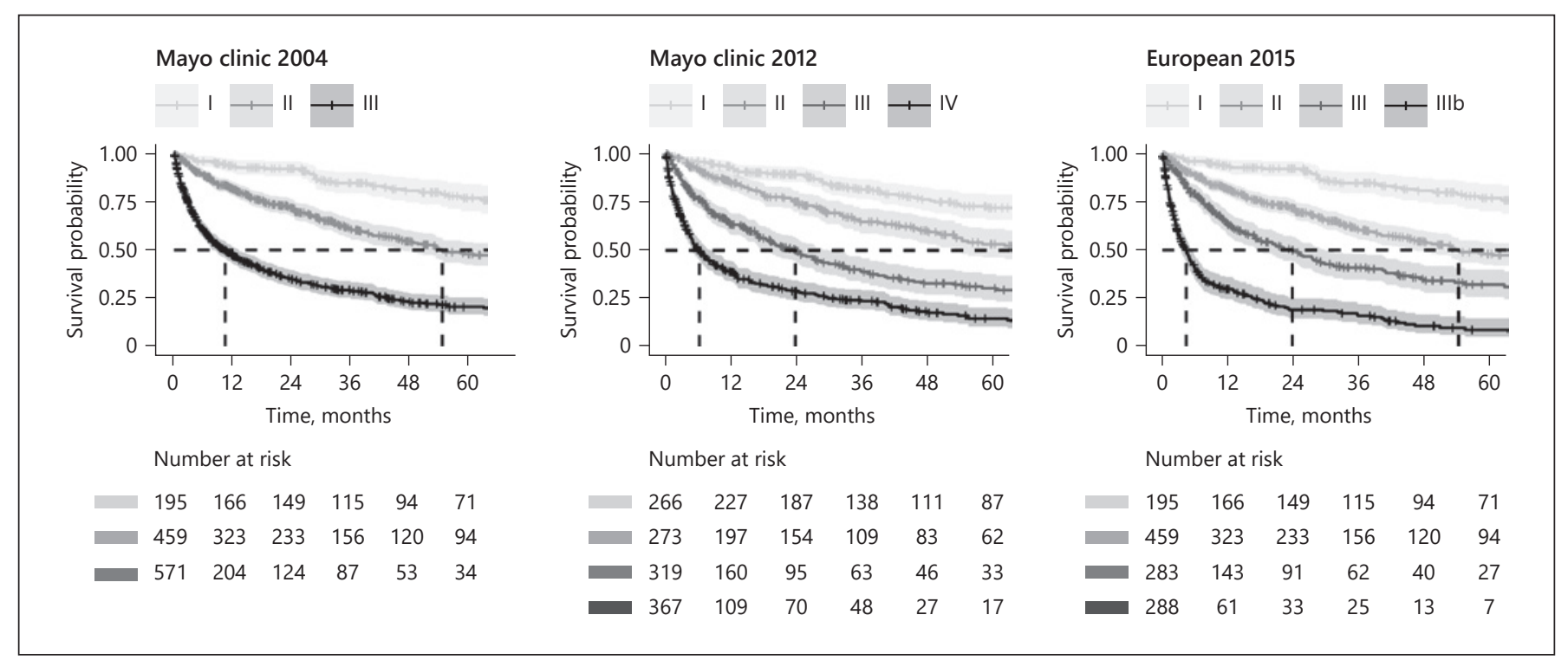

Fig. 1. OS according to cardiac staging systems. Kaplan-Meier plots; shaded areas indicate the 95\% CI (own data, published in Dittrich et al. [35]).

\section{Prognostic Value of Organ Biomarkers in AL Amyloidosis and Staging Systems}

A wide range of organ biomarkers are available that reflect the severity of organ dysfunction and amyloid load in AL patients (Table 2).

\section{Heart}

The morbidity and mortality of AL patients is strongly linked to the severity of heart involvement. Therefore, most of the organ biomarkers with prognostic relevance to $\mathrm{OS}$ in $\mathrm{AL}$ are either representing the cardiac amyloid load (septum thickness), destruction of cardiomyocytes (troponins), or the cardiac dysfunction (LVEF, 2D-GLS, NT-proBNP/BNP, parameters of clinical examination).

Minor myocardial damage can be quantified by the highly specific and sensitive cardiac troponins $\mathrm{T}$ ( $\mathrm{cTnT}$ ) and I (cTnI) [10]. The sensitivity is even increased with high-sensitivity assays (hsTnT) [31]. In response to distension and stretching caused by volume expansion and/ or pressure overload, the prohormone preproBNP is secreted by cardiac myocytes. PreproBNP is then cleaved to proBNP, which is again cleaved to the active hormone BNP and the biologically inactive NT-proBNP with a longer half-life [29]. The negative prognostic value of elevated cardiac troponins and NT-proBNP for survival in AL has been identified and validated in multiple studies, using different cut-offs (Table 2). Both biomarkers were therefore consequentially incorporated into a first widely used staging system for AL [10]. The elevation of either no, one, or both biomarkers forms 3 stages that are associated with tremendous differences in survival (Fig. 1; Table 3). Recently, thresholds for BNP instead of NT-proBNP were proposed by the Amyloidosis Center of the Boston University to use the established AL staging systems with BNP [29].

It was later shown that a second, higher threshold for NT-proBNP at $8,500 \mathrm{pg} / \mathrm{mL}$ as well as low systolic blood pressure can identify a very high-risk group with a median OS of less than 5 months among the patients with both troponins and NT-proBNP elevated, resulting in a system of 4 stages $[28,62]$. Concurrently, plasma cell factors were incorporated in a revised staging system by utilizing serum FLC (threshold $\geq 180 \mathrm{mg} / \mathrm{L}$ ) in combination with NT-proBNP and troponins at different thresholds (Fig. 1; Table 3) [10, 15]. The performance and accuracy of these three widely accepted and used staging systems for AL were recently compared by several retrospective analyses. The 4-stage system using two thresholds for NT-proBNP emerged as superior, especially in comparison to the initial 3-stage system [35, 63]. The main advantage of this staging system is the identification of patients with very high risk for early death after diagnosis. However, based on the comparison data it can be assumed that adding dFLC to a cardiac biomarker-based model increases the ability to predict for long-term survival [63]. In case of relapse, restaging before initiation of the sec- 
Table 3. Cardiac staging systems in AL

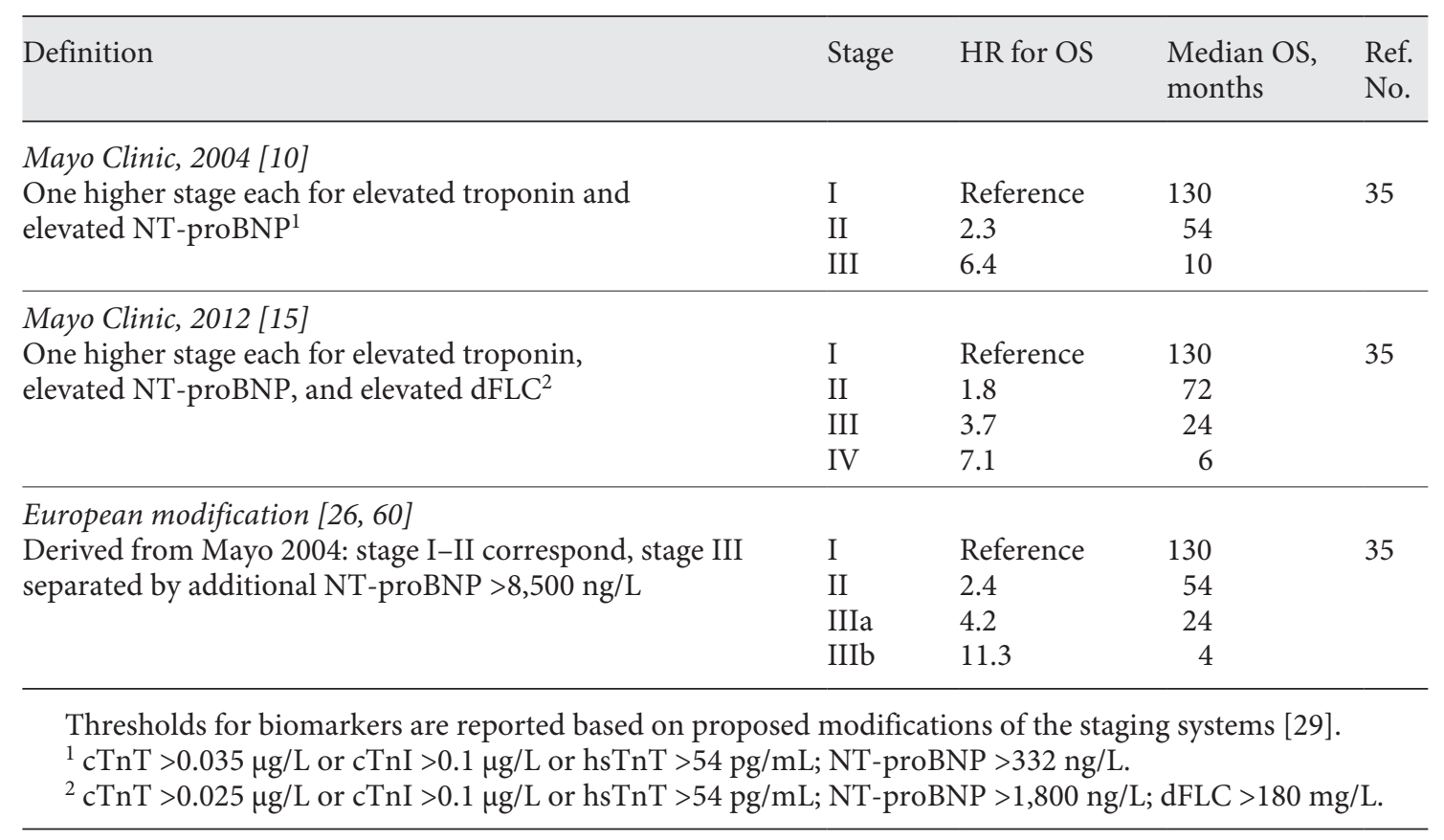

ond-line therapy increases the accuracy of the staging systems. The integration of dFLC into the staging system has even more priority in this case, as very poor responders with severe heart involvement confer a particularly poor prognosis [27].

Frequent clinical complications of cardiac AL are moderate to severe kidney impairment as well as atrial fibrillation. Both conditions are known to increase NTproBNP. This does, however, not decrease the prognostic value of elevated NT-proBNP in these patients [35]. Indeed, atrial fibrillation and kidney impairment are independent negative prognostic factors in $\mathrm{AL}[35,36]$. It has also been shown that serum uric acid levels added to the prognostic value of cTnT and NT-proBNP in multivariate analysis [38]. However, the underlying mechanisms are unknown and elevated uric acid was also strongly associated with impaired kidney function, potentially suggesting uric acid as additional surrogate parameter for impaired kidney function and the use of diuretics in $\mathrm{AL}$ patients [64].

Although not included in current AL staging systems, advanced cardiac imaging modalities such as echocardiography, cardiovascular MRI, radionuclide bone scintigraphy, and PET provide valuable additional prognostic information and are also important for the precise diagnosis and monitoring of the disease [65]. The combinations of multiple echocardiographic parameters are routinely used for
Table 4. Renal staging systems in AL

\begin{tabular}{|c|c|c|}
\hline Definition & Stage & $\begin{array}{l}\text { Patients on dialysis } \\
\text { after } 3 \text { years, } \%\end{array}$ \\
\hline \multicolumn{3}{|l|}{ Palladini et al. [37], 2014} \\
\hline One higher stage each & $\mathrm{I}$ & $0 / 4^{\mathrm{a}}$ \\
\hline for elevated 24-h UPr and & II & $7 / 30^{\mathrm{a}}$ \\
\hline $\mathrm{eGFR}<50$ & III & $60 / 85^{\mathrm{a}}$ \\
\hline \multicolumn{3}{|l|}{ Kastritis et al. [69], 2017} \\
\hline 24-h UPr/eGFR ratio $<30$ & $\mathrm{I}$ & 0 \\
\hline 24-h UPr/eGFR ratio 30-99 & II & 11 \\
\hline 24-h UPr/eGFR ratio $\geq 100$ & III & 46 \\
\hline
\end{tabular}

a Testing cohort/validation cohort.

confirming amyloidogenic organ involvement [66]. Septum thickness, left longitudinal function, and ejection fraction, either measured by echocardiography or MRI, are each prognostic for short-term OS $[9,10,31,32]$. Furthermore, the presence of low peripheral voltages by ECG is associated with a more severe cardiac involvement [67].

\section{Kidney}

The kidney is the second most frequently involved organ in AL patients [68]. For many patients with primarily kidney involvement, renal survival, i.e., the estimated 
Table 5. Hematologic response criteria in $\mathrm{AL}$

\begin{tabular}{|c|c|c|c|c|}
\hline Criterion & Definition & Timepoint & Outcome & Ref. No. \\
\hline $\mathrm{aCR}$ & $\begin{array}{l}\text { No evidence of involved } M \text { component by } \\
\text { serum and urine IFE; FLC ratio normal }\end{array}$ & $\begin{array}{l}3 \text { months } \\
6 \text { months }\end{array}$ & Reference for HR & 43,72 \\
\hline VGPR & If initial dFLC $\geq 50 \mathrm{mg} / \mathrm{L}: \mathrm{dFLC}<40 \mathrm{mg} / \mathrm{L}$ & $\begin{array}{l}3 \text { months } \\
6 \text { months }\end{array}$ & HR 2.67 & 37,72 \\
\hline No response & All other & $\begin{array}{l}3 \text { months } \\
6 \text { months }\end{array}$ & HR 12.34 & 72 \\
\hline Low-dFLC PR & If initial dFLC $20-50 \mathrm{mg} / \mathrm{L}: \mathrm{dFLC}<10 \mathrm{mg} / \mathrm{L}$ & $\begin{array}{l}3 \text { months } \\
6 \text { months }\end{array}$ & $\begin{array}{l}\text { Renal/cardiac response as good } \\
\text { as with aCR }\end{array}$ & $\begin{array}{l}2,14 \\
73-75\end{array}$ \\
\hline $\begin{array}{l}\text { Perspective } \\
\text { Stringent dFLC } \\
\text { response }\end{array}$ & If initial dFLC $\geq 20 \mathrm{mg} / \mathrm{L}$ : $\mathrm{dFLC}<10 \mathrm{mg} / \mathrm{L}$ & 6 months & $\begin{array}{l}\text { Favorable OS, TNT and cardiac re- } \\
\text { sponse compared to CR or VGPR }\end{array}$ & 76 \\
\hline $\begin{array}{l}\text { Stringent } \mathrm{CR}^{1} / \mathrm{MRD} \\
\text { negative }\end{array}$ & $\begin{array}{l}\mathrm{aCR}+\text { no evidence of clonal plasma cells in } \\
\mathrm{BM} \text { by multiparametric flow cytometry } 2\end{array}$ & $\begin{array}{l}100 \text { days } \\
\text { post-ASCT }\end{array}$ & $\begin{array}{l}\text { Longer PFS, better organ response } \\
\text { compared to aCR (statistically non- } \\
\text { significant) }\end{array}$ & $77-80$ \\
\hline
\end{tabular}

CR, complete response; aCR, CR criterium for AL; VGPR, very good partial response; PR, partial response; OS, overall survival; TNT, time to next treatment; PFS, progression-free survival; HR, hazard ratio for death (hematologic and cardiac response) or dialysis (renal response); IFE, immunofixation electrophoresis; FLC, free light chains; iFLC, involved FLC; BM, bone marrow; dFLC, difference of involved minus uninvolved FLC; MRD minimal residual disease.

${ }^{1}$ Monoclonality established by immunohistochemistry, morphology, and flow cytometry.

${ }^{2}$ Currently reported sensitivity: 1 in $1 \times 10^{4}$ to $2 \times 10^{5}$.

living time without end-stage renal disease (ESRD), is the most relevant outcome. Proteinuria or more specifically albuminuria is the hallmark of kidney involvement in AL amyloidosis, while a moderately decreased eGFR can also be caused by advanced cardiac involvement [35].

Two staging systems based on the combination of proteinuria and eGFR have been proposed to estimate the risk of ESRD (Table 4). AL patients with both parameters unaffected have a very low probability of suffering from ESRD, while patients with both parameters affected have a risk of $50 \%$ or higher to develop ESRD within 3 years from the initial diagnosis. Of note, the staging system proposed by Palladini et al. [37] has been independently validated and was also used for comparison by Kastritis et al. [69], while this later proposed staging system has not yet been validated. ESRD rates have varied considerably among the different cohorts evaluated by Palladini et al. [37] and Kastritis et al. [69], which makes comparisons of the results difficult.

Recently, a severe nephrotic range albuminuria has been reported as adverse for outcome (hematologic event-free survival) with daratumumab. Especially in combination with a dFLC $>180 \mathrm{mg} / \mathrm{L}$, satisfying hematologic responses were rare. The suggested mechanism was a constant renal loss of monoclonal antibody in nephrotic patients with consecutive lower daratumumab serum concentrations and insufficient renal target saturation [23].

\section{Liver}

It can be assumed that severe AL liver involvement results in adverse OS [70]. However, the quality and quan- 
Table 6. Organ response criteria in AL

\begin{tabular}{|c|c|c|c|c|}
\hline Criterion & Definition & Timepoint & Outcome & Ref. No. \\
\hline \multicolumn{5}{|l|}{ Cardiac response } \\
\hline NT-proBNP response & $\begin{array}{l}\text { If baseline NT-proBNP } \geq 650 \mathrm{ng} / \mathrm{L} \text { : decrease of }>30 \% \text { and } \\
>300 \mathrm{ng} / \mathrm{L}\end{array}$ & $\begin{array}{l}3 \text { months } \\
6 \text { months }\end{array}$ & HR 0.23 & 12,72 \\
\hline NT-proBNP stable & No increase or decrease of NT-proBNP & $\begin{array}{l}3 \text { months } \\
6 \text { months }\end{array}$ & Reference for HR & 72 \\
\hline NT-proBNP progression & NT-proBNP increase of $>30 \%$ and $>300 \mathrm{ng} / \mathrm{L}$ & $\begin{array}{l}3 \text { months } \\
6 \text { months }\end{array}$ & HR 4.36 & $12,72,81$ \\
\hline cTn progression & $>33 \%$ increase in cTn & 6 months & HR 2.27 & 72 \\
\hline NYHA class response & If baseline NYHA class 3 or $4: \geq$ two-class decrease & 6 months & HR 0.28 & 72 \\
\hline EF progression & $\geq 10 \%$ decrease in $\mathrm{EF}$ & 6 months & HR 1.95 & 72 \\
\hline \multicolumn{5}{|l|}{ Renal response } \\
\hline $\begin{array}{l}\text { Renal response } \\
\text { (Palladini et al. [37]) }\end{array}$ & $\begin{array}{l}\geq 30 \% \text { decrease in proteinuria or drop of proteinuria below } \\
0.5 \mathrm{~g} / 24 \mathrm{~h} \text { in the absence of renal progression }\end{array}$ & $\begin{array}{l}3 \text { months } \\
6 \text { months }\end{array}$ & HR 0.25 & 37 \\
\hline $\begin{array}{l}\text { Renal progression } \\
\text { (Palladini et al. [37]) }\end{array}$ & $\geq 25 \%$ decrease in eGFR & $\begin{array}{l}3 \text { months } \\
6 \text { months }\end{array}$ & HR 4.74 & 37,43 \\
\hline $\begin{array}{l}\text { Renal response } \\
(\text { Kastritis et al. [69] })^{1}\end{array}$ & $\begin{array}{l}\text { Reduction of } 24-h \text { UPr/eGFR ratio by at least } 25 \% \text { from baseline } \\
\text { and below } 100 \text { (if } \geq 100)\end{array}$ & $\begin{array}{l}3 \text { months } \\
6 \text { months }\end{array}$ & $\begin{array}{l}\text { ESRD within } 2 \text { years: } \\
0 \text { vs } 24 \% \\
0 \text { vs. } 22 \%\end{array}$ & 69 \\
\hline $\begin{array}{l}\text { Renal progression } \\
(\text { Kastritis et al. [69] })^{1}\end{array}$ & Increase of 24 -hUPr/eGFR ratio by at least $25 \%$ from baseline or $\geq 100$ & 3 months & $\begin{array}{l}\text { ESRD within } 2 \text { years: } \\
22 \text { vs } 2.5 \%\end{array}$ & 69 \\
\hline \multicolumn{5}{|l|}{ Hepatic response } \\
\hline Hepatic response & $\begin{array}{l}50 \% \text { decrease in abnormal alkaline phosphatase (AP) value } \\
\text { Decrease in liver size radiographically at least } 2 \mathrm{~cm}\end{array}$ & & Expert opinion & 43 \\
\hline
\end{tabular}

tity of available biomarkers to quantify liver involvement (serum gamma-GT, AP, Fibroscan) are limited compared to heart and kidney. For the subgroup of AL patients with an underlying IgM, which more frequently have liver involvement, the presence of liver involvement is an independent risk factor [61].

\section{Novel Organ Biomarkers}

As reviewed recently, there is an increasing pool of novel organ biomarkers with potential prognostic value: growth differentiation factor-15, proadrenomedullin, osteopontin, hepatocyte growth factor, soluble suppression of tumorgenicity 2, von Willebrand factor antigen, and osteoprotegerin [71]. The link between amyloidogenic organ damage and biomarker elevation is not yet fully resolved for many of these novel biomarkers and validation of the prognostic value in large case series is warranted. Therefore, these biomarkers have not been incorporated into routine practice yet.

Prognosis and Staging of AL Amyloidosis

\section{Response to Plasma Cell-Directed Therapy}

Many of the factors with upfront prognostic value in AL were confirmed to be useful for monitoring the success of plasma cell-directed therapy and estimate the prognosis of AL patients based on biomarkers after several months of treatment (landmark analysis). These parameters were incorporated in combined hematologic and organ response criteria (Tables 5, 6).

\section{Hematologic Response}

Anti-plasmacellular therapy is the cornerstone of treatment in AL amyloidosis, since the light chain is the precursor of the amyloid protein. The goal of anti-plasmacellular therapy in AL, which is required for an optimal organ response, is the virtual complete eradication of the amyloidogenic light chain [72]. In one retrospective analysis of 313 patients who responded to chemotherapy with a normalization of FLC levels, higher values of the 
FLC at diagnosis (dFLC $>180 \mathrm{mg} / \mathrm{L}$ ) predicted the organ response, and an early normalization of FLC levels predicted an improved OS [82].

The criteria for hematologic response were initially proposed by AL consensus guidelines that were broadly derived from myeloma [43]. However, in contrast to myeloma, less than half the AL patients have a detectable circulating intact Ig paraprotein and in many others the concentration is so low that accurate quantification is not possible. Immunofixation electrophoresis (IFE) is more sensitive than serum or urine protein electrophoresis and can detect free monoclonal immunoglobulin light chains in the urine of $80-90 \%$ of patients, but IFE results are not quantitative. Consequently, conventional immunochemical and electrophoretic techniques generally provide only qualitative measures of hematologic response to treatment in AL amyloidosis [83]. Moreover, in AL, the quality of FLC response is strictly and directly associated with survival [72]. Therefore, the quantitative serum FLC measurement plays a paramount role for response evaluation and normalization of serum FLC ratio and levels were incorporated into the complete response criterium for AL (aCR) early on $[43,83]$. Of note, the prognostic value of the $\mathrm{dFLC}$ response is superior compared to the $M$ protein response [84]. Indeed, the $M$ protein response does not improve survival in those patients without an FLC response [72]. A 50\% decrease of iFLC as well as dFLC upon therapy was found to be associated with significantly improved OS (partial response; PR) $[85,86]$. To achieve organ response in a fraction of patients, a decrease of dFLC below $40 \mathrm{mg} / \mathrm{L}$ should be the minimal goal of therapy (very good PR; VGPR) [72].

Previously, a baseline dFLC of below $50 \mathrm{mg} / \mathrm{L}$ was regarded as "not measurable" for hematologic response [46, 87]. However, not all dFLC changes in AL patients with baseline dFLC between 20 and $50 \mathrm{mg} / \mathrm{L}$ turned out to be meaningful, and based on the renal organ response a threshold of $10 \mathrm{mg} / \mathrm{L}$ was established as an additional hematologic response parameter besides aCR for this specific clinical subgroup ("low dFLC PR") [2, 14, 73-75]. Later, this dFLC response threshold of $10 \mathrm{mg} / \mathrm{L}$ was proposed for all patients with baseline dFLC $>20 \mathrm{mg} / \mathrm{L}$. It has been shown in one large prospective observational study - but not yet validated - that this "stringent dFLC response" translated into a significantly longer time to next treatment and a benefit for OS additional to CR or VGPR [76].

More stringent response criteria will eventually reduce the present number of patients with an apparently satisfying hematologic response who, however, do not achieve a sufficient organ response. Even very small residual plasma cell clones are sufficient to impede organ response in some $\mathrm{AL}$ patients. A stringent complete response was recently proposed as the optimal endpoint after stem cell transplantation, defined as undetectable bone marrow clonal plasma cells by flow cytometry. Progression-free survival was significantly shorter in patients failing to achieve a stringent complete response compared to aCR. A bone marrow examination post-transplant is important because it can identify patients who fail to achieve a stringent complete response and thereby predicts earlier progression [77]. Minimal residual disease (MRD) assessment in AL by next-generation flow cytometry is currently being validated by several groups and the implementation of MRD assessment will further improve response evaluation [78-80].

\section{Organ Response}

Principally, organ response in AL is evaluated by the monitoring of biomarkers used for diagnosis and grading of organ involvement (Tables 5,6). The first organ response criteria was proposed by the ISA in 2005 [43]. Subsequently, outcome-driven criteria were developed - for heart based on OS [72] and for kidney based on renal survival, i.e., time to ESRD $[37,69]$. Recently, it could be demonstrated that graded response criteria $(<30 \%, 31-60 \%$, $>60 \%$ reduction of biomarker from baseline or complete normalization), are able to predict significantly different OS of respective patients $[70,82]$. Validation of these novel criteria within the broader AL community is in progress. Different organ response criteria for subgroup of patients with advanced cardiac AL might be needed with the success of novel fast-acting therapies $[23,28]$.

\section{Conclusion}

The prognosis of AL patients is determined by the biology of the: (1) underlying clonal disease, (2) pattern and extent of organ involvement at baseline, as well as (3) response to treatment. Multiple biomarkers were integrated into validated staging systems. The OS is most appropriately estimated by cardiac staging systems, of which the European modification of the original Mayo staging system by a second threshold for NT-proBNP showed the best performance (Fig. 1). Renal staging systems are powerful in estimating the time to ESRD. Organ response rates and OS were used to further develop hematologic response criteria. The ultimate goal of therapy in AL is to decrease the amyloidogenic-involved light chain as fast and deep as possible without causing significant damage. iFISH is widely used to evaluate cytogenetic aberrations 
in AL plasma cells and even able to predict treatment response. The international AL community is constantly improving staging systems and response criteria. The prognostic value of biomarkers and the performance of staging systems are significantly influenced by currently available treatment options. Therefore, potential novel approaches to directly target the toxic light chains and deposited amyloid might also change the applicability of the current validated AL staging systems.

\section{Disclosure Statement}

The authors have no conflicts of interest to declare.

\section{Funding Sources}

There was no funding in conjunction with the preparation of this manuscript.

\section{Author Contributions}

Conception of the review: T.D., C.K., U.H., S.O.S. Drafting the work: T.D. Revising for important intellectual content: C.K., U.H., S.O.S. Final approval of the version to be published: T.D., C.K., U.H., S.O.S.

\section{References}

1 Kourelis TV, Kumar SK, Gertz MA, Lacy MQ, Buadi FK, Hayman SR, et al. Coexistent multiple myeloma or increased bone marrow plasma cells define equally high-risk populations in patients with immunoglobulin light chain amyloidosis. J Clin Oncol. 2013 Dec; 31(34):4319-24.

2 Dittrich T, Bochtler T, Kimmich C, Becker N, Jauch A, Goldschmidt H, et al. AL amyloidosis patients with low amyloidogenic free light chain levels at first diagnosis have an excellent prognosis. Blood. 2017;130(5):632-42.

3 Tovar N, Rodríguez-Lobato LG, Cibeira MT, Magnano L, Isola I, Rosiñol L, et al. Bone marrow plasma cell infiltration in light chain amyloidosis: impact on organ involvement and outcome. Amyloid. 2018 Jun;25(2):79-85.

4 Zhang CL, Qiu Y, Shen KN, Miao HL, Feng J, Cao XX, et al. Clinical presentation and prognosis of immunoglobulin light-chain amyloidosis with high percentage of bone marrow plasma cells. Leuk Res. 2019 Jun;81:19-24.

5 Muchtar E, Gertz MA, Kourelis TV, Sidana S, Go RS, Lacy MQ, et al. Bone marrow plasma cells $20 \%$ or greater discriminate presentation, response, and survival in AL amyloidosis. Leukemia. 2020;34(4):1135-43.

6 Muchtar E, Jevremovic D, Dispenzieri A, Dingli D, Buadi FK, Lacy MQ, et al. The prognostic value of multiparametric flow cytometry in $\mathrm{AL}$ amyloidosis at diagnosis and at the end of first-line treatment. Blood. 2017; 129(1):82-7.

7 Paiva B, Vídriales MB, Pérez JJ, López-Berges MC, García-Sanz R, Ocio EM, et al. The clinical utility and prognostic value of multiparameter flow cytometry immunophenotyping in light-chain amyloidosis. Blood. 2011 Mar; 117(13):3613-6.

8 Pardanani A, Witzig TE, Schroeder G, McElroy EA, Fonseca R, Dispenzieri A, et al. Circulating peripheral blood plasma cells as a prognostic indicator in patients with primary systemic amyloidosis. Blood. 2003 Feb;101(3):827-30.
9 Dispenzieri A, Kyle RA, Gertz MA, Therneau TM, Miller WL, Chandrasekaran K, et al. Survival in patients with primary systemic amyloidosis and raised serum cardiac troponins. Lancet. 2003 May;361(9371):17879.

10 Dispenzieri A, Gertz MA, Kyle RA, Lacy MQ, Burritt MF, Therneau TM, et al. Serum cardiac troponins and $\mathrm{N}$-terminal pro-brain natriuretic peptide: a staging system for primary systemic amyloidosis. J Clin Oncol. 2004 Sep; 22(18):3751-7.

11 Dispenzieri A, Lacy MQ, Katzmann JA, Rajkumar SV, Abraham RS, Hayman SR, et al. Absolute values of immunoglobulin free light chains are prognostic in patients with primary systemic amyloidosis undergoing peripheral blood stem cell transplantation. Blood. 2006 Apr;107(8):3378-83.

12 Palladini G, Barassi A, Klersy C, Pacciolla R, Milani P, Sarais G, et al. The combination of high-sensitivity cardiac troponin $\mathrm{T}$ (hs-cTnT) at presentation and changes in $\mathrm{N}$-terminal natriuretic peptide type B (NT-proBNP) after chemotherapy best predicts survival in $\mathrm{AL}$ amyloidosis. Blood. 2010 Nov;116(18):342630.

13 Kumar S, Dispenzieri A, Katzmann JA, Larson DR, Colby CL, Lacy MQ, et al. Serum immunoglobulin free light-chain measurement in primary amyloidosis: prognostic value and correlations with clinical features. Blood. 2010 Dec;116(24):5126-9.

14 Milani P, Basset M, Russo F, Foli A, Merlini G, Palladini G. Patients with light-chain amyloidosis and low free light-chain burden have distinct clinical features and outcome. Blood. 2017;130(5):625-31.

15 Kumar S, Dispenzieri A, Lacy MQ, Hayman SR, Buadi FK, Colby C, et al. Revised prognostic staging system for light chain amyloidosis incorporating cardiac biomarkers and serum free light chain measurements. J Clin Oncol. 2012 Mar;30(9):989-95.
16 Muchtar E, Dispenzieri A, Kumar SK, Buadi FK, Lacy MQ, Zeldenrust S, et al. Immunoparesis in newly diagnosed $\mathrm{AL}$ amyloidosis is a marker for response and survival. Leukemia. 2017 Jan;31(1):92-9.

17 Sachchithanantham S, Berlanga O, Alvi A Mahmood SA, Lachmann HJ, Gillmore JD, et al. Immunoparesis defined by heavy+light chain suppression is a novel marker of long-term outcomes in cardiac AL amyloidosis. Br J Haematol. 2017 Nov; 179(4): 575-85.

18 Hammons L, Brazauskas R, Pasquini M, Hamadani M, Hari P, D’Souza A. Presence of fluorescent in situ hybridization abnormalities is associated with plasma cell burden in light chain amyloidosis. Hematol Oncol Stem Cell Ther. 2018 Jun;11(2):105-11.

19 Warsame R, Kumar SK, Gertz MA, Lacy MQ Buadi FK, Hayman SR, et al. Abnormal FISH in patients with immunoglobulin light chain amyloidosis is a risk factor for cardiac involvement and for death. Blood Cancer J. 2015 May;5(5):e310.

20 Bochtler T, Hegenbart U, Kunz C, Granzow M, Benner A, Seckinger A, et al. Translocation $\mathrm{t}(11 ; 14)$ is associated with adverse outcome in patients with newly diagnosed AL amyloidosis when treated with bortezomibbased regimens. J Clin Oncol. 2015 Apr; 33(12):1371-8

21 Muchtar E, Dispenzieri A, Kumar SK, Ketterling RP, Dingli D, Lacy MQ, et al. Interphase fluorescence in situ hybridization in untreated AL amyloidosis has an independent prognostic impact by abnormality type and treatment category. Leukemia. 2017 Jul;31(7): 1562-9.

22 Bochtler T, Hegenbart U, Kunz C, Benner A, Kimmich C, Seckinger A, et al. Prognostic impact of cytogenetic aberrations in AL amyloidosis patients after high-dose melphalan: a long-term follow-up study. Blood. $2016 \mathrm{Jul}$; 128(4):594-602. 
23 Kimmich CR, Terzer T, Benner A, Dittrich T, Veelken K, Carpinteiro A, et al. Daratumumab for systemic AL amyloidosis: prognostic factors and adverse outcome with nephroticrange albuminuria. Blood. $2020 \mathrm{Apr}$;135(18): 1517-30.

24 Bochtler T, Hegenbart U, Kunz C, Benner A, Seckinger A, Dietrich S, et al. Gain of chromosome 1q21 is an independent adverse prognostic factor in light chain amyloidosis patients treated with melphalan/dexamethasone. Amyloid. 2014 Mar;21(1):9-17.

25 Wong SW, Hegenbart U, Palladini G, Shah GL, Landau HJ, Warner M, et al. Outcome of Patients With Newly Diagnosed Systemic Light-Chain Amyloidosis Associated With Deletion of $17 \mathrm{p}$. Clin Lymphoma Myeloma Leuk. 2018 Nov;18(11):e493-9.

26 Palladini G, Campana C, Klersy C, Balduini A, Vadacca G, Perfetti V, et al. Serum N-terminal pro-brain natriuretic peptide is a sensitive marker of myocardial dysfunction in AL amyloidosis. Circulation. 2003 May;107(19):2440-5.

27 Hwa YL, Gertz MA, Kumar SK, Lacy MQ, Buadi FK, Dingli D, et al. Prognostic restaging at the time of second-line therapy in patients with AL amyloidosis. Leukemia. 2019 May; 33(5):1268-72.

28 Wechalekar AD, Schonland SO, Kastritis E, Gillmore JD, Dimopoulos MA, Lane T, et al. A European collaborative study of treatment outcomes in 346 patients with cardiac stage III AL amyloidosis. Blood. 2013 Apr;121(17): $3420-7$.

29 Lilleness B, Ruberg FL, Mussinelli R, Doros G, Sanchorawala V. Development and validation of a survival staging system incorporating BNP in patients with light chain (AL) amyloidosis. Blood. 2019;133(3):215-23.

30 Dispenzieri A, Gertz MA, Kumar SK, Lacy MQ, Kyle RA, Saenger AK, et al. High sensitivity cardiac troponin $\mathrm{T}$ in patients with immunoglobulin light chain amyloidosis. Heart. 2014 Mar;100(5):383-8.

31 Kristen AV, Giannitsis E, Lehrke S, Hegenbart U, Konstandin M, Lindenmaier D, et al. Assessment of disease severity and outcome in patients with systemic light-chain amyloidosis by the high-sensitivity troponin $\mathrm{T}$ assay. Blood. 2010 Oct;116(14):2455-61.

32 Arenja N, Andre F, Riffel JH, Siepen FA dem, Hegenbart U, Schönland S, et al. Prognostic value of novel imaging parameters derived from standard cardiovascular magnetic resonance in high risk patients with systemic light chain amyloidosis. J Cardiovasc Magn Reson. 2019;21(1):53.

33 Buss SJ, Emami M, Mereles D, Korosoglou G, Kristen AV, Voss A, et al. Longitudinal left ventricular function for prediction of survival in systemic light-chain amyloidosis: incremental value compared with clinical and biochemical markers. J Am Coll Cardiol. 2012 Sep;60(12):1067-76.

34 Pun SC, Landau HJ, Riedel ER, Jordan J, Yu AF, Hassoun $\mathrm{H}$, et al. Prognostic and Added Value of Two-Dimensional Global Longitudinal
Strain for Prediction of Survival in Patients with Light Chain Amyloidosis Undergoing Autologous Hematopoietic Cell Transplantation. J Am Soc Echocardiogr. 2018 Jan;31(1):64-70.

35 Dittrich T, Benner A, Kimmich C, Siepen F aus dem, Veelken K, Kristen AV, et al. Performance analysis of AL amyloidosis cardiac biomarker staging systems with special focus on renal failure and atrial arrhythmia. Haematologica. 2019;104(7):1451-9.

36 Sidana S, Tandon N, Brady PA, Grogan M, Gertz MA, Dispenzieri A, et al. Prognostic Significance of Holter Monitor Findings in Patients With Light Chain Amyloidosis. Mayo Clin Proc. 2019 Mar;94(3):455-64

37 Palladini G, Hegenbart U, Milani P, Kimmich C, Foli A, Ho AD, et al. A staging system for renal outcome and early markers of renal response to chemotherapy in AL amyloidosis. Blood. 2014 Oct;124(15):2325-32.

38 Kumar S, Dispenzieri A, Lacy MQ, Hayman SR, Leung N, Zeldenrust SR, et al. Serum uric acid: novel prognostic factor in primary systemic amyloidosis. Mayo Clin Proc. 2008 Mar;83(3):297-303.

39 Sidana S, Tandon N, Gertz MA, Dispenzieri A, Ramirez-Alvarado M, Murray DL, et al. Clinical features, laboratory characteristics and outcomes of patients with renal versus cardiac light chain amyloidosis. Br J Haematol. 2019 May;185(4):701-7.

40 Abraham RS, Katzmann JA, Clark RJ Bradwell AR, Kyle RA, Gertz MA. Quantitative analysis of serum free light chains. A new marker for the diagnostic evaluation of primary systemic amyloidosis. Am J Clin Pathol. 2003 Feb;119(2):274-8.

41 Bochtler T, Hegenbart U, Heiss C, Benner A, Cremer F, Volkmann M, et al. Evaluation of the serum-free light chain test in untreated patients with AL amyloidosis. Haematologica. 2008 Mar;93(3):459-62.

42 Lock RJ, Saleem R, Roberts EG, Wallage MJ, Pesce TJ, Rowbottom A, et al. A multicentre study comparing two methods for serum free light chain analysis. Ann Clin Biochem. 2013 May;50(Pt 3):255-61.

43 Gertz MA, Comenzo R, Falk RH, Fermand JP, Hazenberg BP, Hawkins PN, et al. Definition of organ involvement and treatment response in immunoglobulin light chain amyloidosis $(\mathrm{AL})$ : a consensus opinion from the 10th International Symposium on Amyloid and Amyloidosis, Tours, France, 18-22 April 2004. Am J Hematol. 2005 Aug;79(4):319-28.

44 Katzmann JA, Clark RJ, Abraham RS, Bryant S, Lymp JF, Bradwell AR, et al. Serum reference intervals and diagnostic ranges for free kappa and free lambda immunoglobulin light chains: relative sensitivity for detection of monoclonal light chains. Clin Chem. 2002 Sep;48(9):1437-44.

45 Palladini G, Milani P, Foli A, Basset M, Russo $\mathrm{F}$, Bosoni $\mathrm{T}$, et al. The impact of renal function on the clinical performance of FLC measurement in AL amyloidosis. Clin Chem Lab Med. 2016 Jun;54(6):939-45.
46 Dispenzieri A, Zhang L, Katzmann JA, Snyder M, Blood E, Degoey R, et al. Appraisal of immunoglobulin free light chain as a marker of response. Blood. 2008 May;111(10):4908-15.

47 Dispenzieri A, Arendt B, Dasari S, Kohlhagen M, Kourelis T, Kumar SK, et al. Blood mass spectrometry detects residual disease better than standard techniques in light-chain amyloidosis. Blood Cancer J. 2020 Feb;10(2):20.

48 Lisenko K, Schönland SO, Jauch A, Andrulis $\mathrm{M}$, Röcken $\mathrm{C}, \mathrm{Ho} \mathrm{AD}$, et al. Flow cytometrybased characterization of underlying clonal $\mathrm{B}$ and plasma cells in patients with light chain amyloidosis. Cancer Med. 2016 Jul;5(7): 1464-72.

49 Shaughnessy J Jr, Tian E, Sawyer J, McCoy J, Tricot G, Jacobson J, et al. Prognostic impact of cytogenetic and interphase fluorescence in situ hybridization-defined chromosome 13 deletion in multiple myeloma: early results of total therapy II. Br J Haematol. 2003 Jan; 120(1):44-52.

50 Bryce AH, Ketterling RP, Gertz MA, Lacy M, Knudson RA, Zeldenrust S, et al. Translocation $\mathrm{t}(11 ; 14)$ and survival of patients with light chain (AL) amyloidosis. Haematologica. 2009 Mar;94(3):380-6.

51 Bochtler T, Hegenbart U, Cremer FW, Heiss C, Benner A, Hose D, et al. Evaluation of the cytogenetic aberration pattern in amyloid light chain amyloidosis as compared with monoclonal gammopathy of undetermined significance reveals common pathways of karyotypic instability. Blood. 2008 May; 111(9):4700-5.

52 Hayman SR, Bailey RJ, Jalal SM, Ahmann GJ, Dispenzieri A, Gertz MA, et al. Translocations involving the immunoglobulin heavychain locus are possible early genetic events in patients with primary systemic amyloidosis. Blood. 2001 Oct;98(7):2266-8.

53 Bochtler T, Hegenbart U, Heiss C, Benner A, Moos M, Seckinger A, et al. Hyperdiploidy is less frequent in $\mathrm{AL}$ amyloidosis compared with monoclonal gammopathy of undetermined significance and inversely associated with translocation t(11;14). Blood. $2011 \mathrm{Apr}$; 117(14):3809-15.

54 Bodet L, Gomez-Bougie P, Touzeau C, Dousset C, Descamps G, Maïga S, et al. ABT-737 is highly effective against molecular subgroups of multiple myeloma. Blood. 2011 Oct; 118(14):3901-10.

55 Gertz MA, Dispenzieri A, Muchtar E. Importance of FISH genetics in light chain amyloidosis. Oncotarget. 2017 Sep;8(47):81735-6.

56 Merlini G, Dispenzieri A, Sanchorawala V, Schönland SO, Palladini G, Hawkins PN, et al. Systemic immunoglobulin light chain amyloidosis. Nat Rev Dis Primers. 2018; $4(1): 38$

57 Basali D, Chakraborty R, Rybicki L, Rosko N, Reed J, Karam M, et al. Real-world data on safety and efficacy of venetoclax-based regimens in relapsed/refractory $\mathrm{t}(11 ; 14)$ multiple myeloma. Br J Haematol. 2020. DOI: 10.1111/ bjh.16454. 
58 Gran C, Borg Bruchfeld J, Ellin F, Nahi H. Rapid complete response to single-agent Bcl2 inhibitor venetoclax in a heart-transplanted patient with triple refractory immunoglobulin light-chain amyloidosis. Acta Haematol. 2020. DOI: $10.1159 / 000504355$.

59 Leung N, Thomé SD, Dispenzieri A. Venetoclax induced a complete response in a patient with immunoglobulin light chain amyloidosis plateaued on cyclophosphamide, bortezo$\mathrm{mib}$ and dexamethasone. Haematologica. 2018 Mar;103(3):e135-7.

60 Sidana S, Larson DP, Greipp PT, He R, McPhail ED, Dispenzieri A, et al. IgM AL amyloidosis: delineating disease biology and outcomes with clinical, genomic and bone marrow morphological features. Leukemia. 2020; 34(5):1373-82.

61 Sachchithanantham S, Roussel M, Palladini G, Klersy C, Mahmood S, Venner CP, et al. European Collaborative Study Defining Clinical Profile Outcomes and Novel Prognostic Criteria in Monoclonal Immunoglobulin MRelated Light Chain Amyloidosis. J Clin Oncol. 2016 Jun;34(17):2037-45.

62 Palladini G, Sachchithanantham S, Milani P, Gillmore J, Foli A, Lachmann H, et al. A European collaborative study of cyclophosphamide, bortezomib, and dexamethasone in upfront treatment of systemic AL amyloidosis. Blood. 2015 Jul;126(5):612-5.

63 Muchtar E, Therneau TM, Larson DR, Gertz MA, Lacy MQ, Buadi FK, et al. Comparative analysis of staging systems in AL amyloidosis. Leukemia. 2019 Mar;33(3):811-4.

64 El-Sheikh AA, van den Heuvel JJ, Koenderink JB, Russel FG. Effect of hypouricaemic and hyperuricaemic drugs on the renal urate efflux transporter, multidrug resistance protein 4. Br J Pharmacol. 2008 Dec;155(7):1066-75.

65 Martinez-Naharro A, Baksi AJ, Hawkins PN, Fontana M. Diagnostic imaging of cardiac amyloidosis. Nat Rev Cardiol. 2020. DOI: 10.1038/s41569-020-0334-7.

66 Boldrini M, Cappelli F, Chacko L, RestrepoCordoba MA, Lopez-Sainz A, Giannoni A, et al. Multiparametric echocardiography scores for the diagnosis of cardiac amyloidosis. JACC Cardiovasc Imaging. 2020;13(4):909-20.

67 Mussinelli R, Salinaro F, Alogna A, Boldrini M, Raimondi A, Musca F, et al. Diagnostic and prognostic value of low QRS voltages in cardiac AL amyloidosis. Ann Noninvasive Electrocardiol. 2013 May;18(3):271-80.

68 Kimmich C, Schönland S, Kräker S, Andrulis M, Ho AD, Mayer G, et al. Amyloid in bone marrow smears in systemic light-chain amyloidosis. Amyloid. 2017 Mar;24(1):52-9.
69 Kastritis E, Gavriatopoulou M, Roussou M, Migkou M, Fotiou D, Ziogas DC, et al. Renal outcomes in patients with AL amyloidosis: prognostic factors, renal response and the impact of therapy. Am J Hematol. 2017 Jul;92(7): 632-9.

70 Muchtar E, Dispenzieri A, Leung N, Lacy MQ, Buadi FK, Dingli D, et al. Depth of organ response in AL amyloidosis is associated with improved survival: grading the organ response criteria. Leukemia. 2018 Oct;32(10): 2240-9.

71 Cohen OC, Wechalekar AD. Systemic amyloidosis: moving into the spotlight. Leukemia. 2020 May;34(5):1215-28.

72 Palladini G, Dispenzieri A, Gertz MA, Kumar S, Wechalekar A, Hawkins PN, et al. New criteria for response to treatment in immunoglobulin light chain amyloidosis based on free light chain measurement and cardiac biomarkers: impact on survival outcomes. J Clin Oncol. 2012 Dec;30(36):4541-9.

73 Sidana S, Tandon N, Dispenzieri A, Gertz MA, Buadi FK, Lacy MQ, et al. Clinical presentation and outcomes in light chain amyloidosis patients with non-evaluable serum free light chains. Leukemia. 2018 Mar;32(3):72935.

74 Nguyen VP, Rosenberg A, Mendelson LM, Comenzo RL, Varga C, Sanchorawala V. Outcomes of patients with AL amyloidosis and low serum free light chain levels at diagnosis. Amyloid. 2018 Sep;25(3):156-9.

75 Qiu Y, Zhang CL, Shen KN, Su W, Feng J, Zhang L, et al. Clinical presentation and prognosis of light-chain amyloidosis patients with unmeasurable free light-chain levels. Ann Hematol. 2018 Dec;97(12):2465-70.

76 Manwani R, Cohen O, Sharpley F, Mahmood S, Sachchithanantham S, Foard D, et al. A prospective observational study of 915 patients with systemic AL amyloidosis treated with upfront bortezomib. Blood. 2019 Dec: 134(25):2271-80.

77 Sidiqi MH, Aljama MA, Jevremovic D, Muchtar E, Buadi FK, Warsame R, et al. Prognostic Significance of Stringent Complete Response after Stem Cell Transplantation in Immunoglobulin Light Chain Amyloidosis. Biol Blood Marrow Transplant. 2018 Nov;24(11): $2360-4$.

78 Muchtar E, Dispenzieri A, Jevremovic D, Dingli D, Buadi FK, Lacy MQ, et al. Survival impact of achieving minimal residual negativity by multi-parametric flow cytometry in AL amyloidosis. Amyloid. 2020 Mar;27(1):13-6.
79 Sidana S, Muchtar E, Sidiqi MH, Jevremovic D, Dispenzieri A, Gonsalves W, et al. Impact of minimal residual negativity using next generation flow cytometry on outcomes in light chain amyloidosis. Am J Hematol. 2020 May; 95(5):497-502.

80 Staron A, Burks EJ, Lee JC, Sarosiek S, Sloan JM, Sanchorawala V. Assessment of minimal residual disease using multiparametric flow cytometry in patients with AL amyloidosis. Blood Adv. 2020 Mar;4(5):880-4.

81 Palladini G, Lavatelli F, Russo P, Perlini S, Perfetti V, Bosoni T, et al. Circulating amyloidogenic free light chains and serum $\mathrm{N}$-terminal natriuretic peptide type $\mathrm{B}$ decrease simultaneously in association with improvement of survival in AL. Blood. 2006 May; 107(10):3854-8.

82 Muchtar E, Dispenzieri A, Leung N, Lacy MQ, Buadi FK, Dingli D, et al. Depth of organ response in AL amyloidosis is associated with improved survival: new proposed organ response criteria. Amyloid. 2019;26(supl 1): 101-2.

83 Sanchorawala V, Seldin DC, Magnani B, Skinner M, Wright DG. Serum free lightchain responses after high-dose intravenous melphalan and autologous stem cell transplantation for AL (primary) amyloidosis. Bone Marrow Transplant. 2005 Oct;36(7): 597-600.

84 Kumar SK, Dispenzieri A, Lacy MQ, Hayman SR, Buadi FK, Zeldenrust SR, et al. Changes in serum-free light chain rather than intact monoclonal immunoglobulin levels predicts outcome following therapy in primary amyloidosis. Am J Hematol. 2011 Mar;86(3):2515.

85 Lachmann HJ, Gallimore R, Gillmore JD, Carr-Smith HD, Bradwell AR, Pepys MB, et al. Outcome in systemic AL amyloidosis in relation to changes in concentration of circulating free immunoglobulin light chains following chemotherapy. Br J Haematol. 2003 Jul; 122(1):78-84.

86 Mahmood S, Venner CP, Sachchithanantham S, Lane T, Rannigan L, Foard D, et al. Lenalidomide and dexamethasone for systemic AL amyloidosis following prior treatment with thalidomide or bortezomib regimens. $\mathrm{Br} \mathrm{J}$ Haematol. 2014 Sep;166(6):842-8.

87 Comenzo RL, Reece D, Palladini G, Seldin D, Sanchorawala V, Landau H, et al. Consensus guidelines for the conduct and reporting of clinical trials in systemic light-chain amyloidosis. Leukemia. 2012 Nov;26(11):2317-25. 